\title{
Gambaran Interaksi Sosial Anak Autis Di Sekolah Inklusi Multi Talenta Samarinda
}

\author{
Jenita Ekasilvita Noya \\ Krismi Diah Ambarwati \\ Fakultas Psikologi Universitas Kristen Satya Wacana \\ jenitanoya77@gmail.com, k_ambarwati@hotmail.com
}

\begin{abstract}
Abstrak
Penelitian ini bertujuan untuk mengetahui gambaran interaksi sosial anak autis di Sekolah Inklusi Multi Talenta Samarinda. Metode yang digunakan dalam penelitian ini adalah penelitian kualitatif dengan pendekatan studi kasus dengan 2 (dua) partisipan anak laki-laki dan perempuan. Metode pengumpulan data dilakukan dengan observasi dari Autism Disorder (AD) Questionnaire for parent, PMII activity observation for young children, dan observation form for recording symtomps that may reflect autistic disorder and positive behaviors. Selanjutnya dilakukan dengan wawancara pada orangtua dan guru berdasarkan 4 (empat) faktor interaksi sosial dan observation guidelines. Hasil dari penelitian ini memunculkan gambaran dari interaksi sosial kedua partisipan seperti pola komunikasi, pola bermain, perasaan atau emosi, perilaku positif, respon sosial, dan interaksi saudara kandung.
\end{abstract}

Kata kunci: interaksi sosial, anak, autisme, sekolah inklusi

\begin{abstract}
This research aims to know the description of the social interaction of autistic children in school with the inclusion of Multi Talenta Samarinda. This method is used in this research in qualitative research with approach case studies wtih 2 (two) participant in boys and girls. The collection of data carried out by methods of observation using the recording frequency for parent of observation of Autism Disorder (AD) quetionnaire for parents PMMI observation for children, and to observation form for recording the symtompsof autistic disorders and may reflect positive behavior. Furthermore, conducted the interview at Foundry and teachers based on four (4) factior of social interactions and observations of the guidelines. The results of this research brings up an overview of social interaction both participant such as the communicationpattern, patterns of play, feelings or emotions, positive behaviors, social interactions and responses of siblings.
\end{abstract}

Keyword: social interaction, children, autism, inclusion school 


\section{PENDAHULUAN}

Dewasa ini, anak berkebutuhan khusus di Indonesia terus meningkat jumlahnya terkhusus pada anak penyandang autisme yang dapat mencapai 150-200 ribu orang (Huzaemah, 2010). Autisme dapat didefinisikan sebagai gangguan perkembangan dengan tiga trias gangguan perkembangan yaitu gangguan pada interaksi sosial, gangguan pada komunikasi, dan keterbatasan minat serta kemampuan imajinasi (Baron-Cohen, 2005).

Autisme masih menjadi mimpi buruk bagi sebagian besar orang tua. Beberapa orang tua langsung stres saat mendengar anaknya didiagnosis autis (Yosep, 2010). Kemudian orang tua yang memiliki anak penyandang autisme segala sesuatunya pasti tampak berbeda dengan orang tua lainnya. Orang tua yang memiliki anak autis, inilah periode awal kehidupan anaknya yang merupakan masa-masa yang tersulit dan paling membebani. Tidak saja berasal dari anaknya, tetapi bercampur dengan masalah-masalah lainnya yang dapat membebani orang tua, termasuk permasalahan yang muncul dari reaksi masyarakat (Safaria, 2005).

Prevalensi gangguan autisme terjadi kira-kira 5 kasus per 10.000 anak atau 0,05\%, anak laki-laki lebih sering terkena gangguan autis dibandingkan anak perempuan (Kaplan \& Sadock, 2010). Jumlah penduduk Indonesia juga lebih dari 237,5 juta dengan laju pertumbuhan penduduk sebesar $1,14 \%$, sehingga jumlah penyandang autisme di Indonesia mencapai 2,4 juta orang (Badan Pusat Statistik, 2010).

Dalam melakukan diagnosa terhadap anak autis, tentunya memerlukan panduan untuk melakukan asesmen. Menurut American Psychiatric Association dalam Diagnostic and Statistical Manual of Mental Disorder fifth Ediiton (2013) autism dikenal dengan sebutan autism spectrum disorder (ASD). Adapun Kriteria Diagnostik pada anak autis dalam DSM-V yakni kurangnya komunikasi dan interaksi sosial di berbagai konteks, aktivitas yang terwujud minimal 2 dari perilaku berikut; Pertama, kurangnya kemampuan dalam hubungan timbal balik sosial-emosional, misalnya dari pendekatan sosial yang tidak normal dan kegagalan percakapan normal, untuk mengurangi pembagian minat, emosi, atau pengaruh, kegagalan untuk memulai atau merespon interaksi sosial. Kedua, terganggu dalam perilaku komunikatif non-verbal yang digunakan untuk interaksi sosial, misalnya komunikasi verbal dan non-verbal yang kurang terintegrasi; kelainan pada kontak mata dan gerak tubuh serta tanpa ekspresi wajah dan komunikasi non-verbal total. Ketiga, kurangnya dalam mengembangkan, memelihara dan memahami hubungan. Misalnya dari kesulitan menyesuaikan perilaku agar sesuai dengan berbagai konteks sosial; untuk kesulitan dalam berbagi permainan imajinatif atau berteman dan tidak adanya ketertarikan pada teman sebayanya.

Beberapa intervensi seperti terapi yang dapat dilakukan pada anak autis diantaranya yakni; terapi wicara, terapi biomedik, terapi makanan, terapi perilaku dan terapi bermain. Selain itu intervensi tidak hanya dilakukan di tempat-tempat terapi tertentu, tetapi intervensi 
tersebut dapat dilakukan dalam setting pendidikan. Di Indonesia, pendidikan khusus dilaksanakan melalui dua jalur, yaitu pada satuan pendidikan akademis (SLB) dan pada sekolah reguler (Program Pendidikan Inklusif). Sekolah inklusi merupakan konsep pendidikan yang merangkul semua anak tanpa terkecuali, inklusi berasumsi bahwa hidup dan belajar bersama adalah suatu cara yang lebih baik, yang dapat memberikan keuntungan bagi setiap orang bukan hanya anak-anak yang diberi label sebagai yang memiliki suatu perbedaan (Skjorten, 2003). Sekolah inklusi menjadi salah satu upaya dari pemerintah untuk menyamaratakan hak berpendidikan untuk setiap warga negaranya. Seperti pada UndangUndang No 70 tahun 2009 mengenai kebijakan pendidikan inklusi yakni sistem penyelenggaraan pendidikan yang memberikan kesempatan kepada semua peserta didik yang memiliki kelainan dan memiliki potensi kecerdasan dan/atau bakat istimewa untuk mengikuti pendidikan atau pembelajaran dalam lingkungan pendidikan secara bersama-sama dengan peserta didik pada umumnya (Permendiknas, 2009).

Selain belajar akademik, terkhususnya anak autis juga belajar untuk berinteraksi dengan teman sesama berkebutuhan khusus dan teman atau orang-orang normal di lingkungan sekitarnya. Keterbatasan anak autis seringkali menyebabkan mereka menarik diri dari sosialisasi dan interaksi di kelas dimana anak yang normal mempunyai prestasi yang jauh di luar jangkauannya (Rahayu, 2017). Gilin dan Gilin (dalam Baron \& Byrne, 2004) mendefinisikan interaksi sosial sebagai hubungan-hubungan antara orang perorangan antara kelompok manusia maupun antar orang perorangan dengan kelompok manusia. Berdasarkan definisi yang telah dijabarkan, interaksi sosial memiliki 4 (empat) faktor penting yang mendasari terjadinya interaksi sosial tersebut, yakni; Pertama, faktor imitasi adalah proses belajar dengan cara meniru atau mengikuti perilaku orang lain (Sunaryo, 2013). Kedua, faktor sugesti adalah cara pemberian suatu pandangan atau pengaruh oleh seseorang dan membuatnya seolah-olah berada dalam keadaan lain (Soekanto, 2013). Ketiga, faktor identifikasi yang berarti menjadi identik dengan orang lain atau rasa ingin sama dengan orang lain (Soekanto, 2013). Keempat, faktor simpati adalah perasaan tertarik yang timbul pada diri seseorang dan membuatnya merasa seolah-olah berada dalam keadaan yang lain (Soekanto, 2013).

Menurut American Psychiatric Association (2000) kelemahan interaksi sosial pada anak autis seperti ditandai dengan kelemahan menggunakan perilaku non-verbal, kegagalan dalam mengembangkan pertemanan, kurangnya rasa spontan untuk berusaha berbagi kesenangan, minat atau prestasi dengan orang lain dan kurangnya timbal balik sosial dan emosional. Kemudian interaksi sosial bagi anak autis tidak hanya dilakukan di dalam setting sekolah tetapi juga di rumah dan di area masyarakat. Bellini (2006b) mengungkapkan hal terpenting dalam interaksi sosial anak autis pada setting sekolah yakni mengembangkan pertemanan. 
Selain itu, kategori batasan pada interaksi sosial anak autis seperti tersenyum, memberi salam, bergabung dengan percakapan, membantu, berbagi, memperhatikan bersama, dan mengontrol agresi seperlunya untuk interaksi sosial yang memadai (NASP, 2002). Selain kategori tersebut, ada pula interaksi sosial positif lainnya seperti: mengenali emosi, memuji, kontak fisik, meminta informasi, memberikan informasi, bergiliran, adanya kontak mata, mendengarkan, berpartisipasi, mengekspresikan antusiasme, dan memperluas ajakan (Cooke \& Appolloni, 1976). Selain itu, menurut Cooper, Giffith \& Filer (dalam William et al, 2006) anak autis perlu diberikan pengajaran atau pelatihan sosial seperti mempertahankan kontak mata dan memulai percakapan.

Dari hasil temuan penelitian mengenai interaksi sosial anak autis di sekolah inklusi yang telah dilakukan oleh Rahayu (2017) di SD Al Firdaus mengungkapkan bahwa interaksi sosial anak autis dengan tingkatan ringan, masih dapat berkomunikasi dengan anak normal, tetapi anak autis dengan tingkatan berat hanya akan dapat berinteraksi atau cocok dengan anak autis yang satu tingkatan seperti dirinya. Kemudian, jika dengan anak normal hanya sekedar berteman, tetapi tidak memiliki hubungan interaksi atau tidak memiliki kecocokan dan interaksinya hanya sekedar diam. Anak autis cenderung lebih suka menyendiri daripada bermain dengan temannya. Selain itu, dari hasil studi pendahuluan mengenai interaksi sosial anak autis yang telah dilakukan di SLB-B dan Autis TPA di Kabupaten Jember dengan hasil wawancara mengungkapkan bahwa siswa autis lebih suka menyendiri dan lebih suka bermain sendiri daripada bermain dengan temannya. Hal tersebut mengindikasikan bahwa anak autis tersebut memiliki kemampuan interaksi sosial yang masih kurang (Deshinta et al, 2015).

Berdasarkan beberapa penelitian yang telah dipaparkan di atas, diketahui bahwa interaksi sosial anak autis yang ditempatkan bersama-sama dengan anak normal maupun dengan guru di sekolah inklusi maupun SLB masih belum terjalin dengan baik dan masih pasif terhadap lingkungan sekitarnya. Sekolah inklusi Multi Talenta Samarinda menjadi salah satu sekolah yang mencampur anak berkebutuhan khusus seperti anak autis dengan anak normal lainnya dalam satu kelas. Interaksi sosial juga menjadi salah satu sasaran sekolah untuk melatih setiap anak berkebutuhan khusus maupun anak normal untuk dapat hidup dalam lingkungan bermasyarakat. Peneliti memilih sekolah inklusi Multi Talenta dengan alasan bahwa pihak sekolah inklusi Multi Talenta menggunakan beberapa metode pengajaran yang tidak hanya mengarahkan siswa pada bagian akademik tetapi juga mengarahkan siswasiswanya terutama siswa autisme untuk dapat berinteraksi dengan teman-teman sekelasnya sesama anak berkebutuhan khusus dan siswa reguler. Program-program tersebut seperti program montessori, fonetik dan ABA. Selanjutnya, program non-akademik seperti kepramukaan, program ekskul, dan program kelas talenta.

Di dalam penelitian ini, peneliti akan mengangkat topik mengenai interaksi sosial anak autis dengan karakteristik dan ciri khas dari 2 partisipan yang akan diteliti. Sesuai dengan 
penelitian Kumalaningrum (2012) menyatakan bahwa anak autis yang satu tidak dapat disamakan dengan anak autis yang lain karena keunikan dan kekhasan masing-masing. Autisme juga lebih sering terjadi pada anak laki-laki daripada anak perempuan dengan rasio 4:1 untuk anak laki-laki dan perempuan. Namun anak perempuan akan menunjukkan gejala yang lebih berat (Sari, 2009). Keunikan pada penelitian ini adalah kedua partisipan berjenis kelamin laki-laki dan perempuan dengan umur yang berbeda. Namun, pada partisipan perempuan merupakan anak autis dengan golongan autis ringan dan kedua partisipan merupakan anak pertama dari tiga bersaudara.

Penelitian ini penting untuk dilakukan, guna mengetahui sejauh mana anak autis dapat melakukan interaksi sosial dengan lingkungannya di sekolah maupun di rumah. Selanjutnya, penelitian ini bertujuan untuk mengetahui gambaran interaksi sosial anak autis di sekolah inklusi Multi Talenta Samarinda.

\section{METODE PENELITIAN}

Metode penelitian yang digunakan dalam penelitian ini adalah metode penelitian kualitatif dengan pendekatan studi kasus. Penelitian studi kasus merupakan pendekatan kualitatif yang penelitinya mengeksplorasi kehidupan-nyata, sistem terbatas kontemporer (kasus) atau beragam sistem terbatas (berbagai kasus), melalui pengumpulan data yang detail dan mendalam yang melibatkan beragam sumber informasi atau sumber infomasi majemuk (misalnya pengamatan, wawancara, bahan audiovisual, dan dokumen dan berbagai laporan), dan melaporkan deskripsi kasusdan tema kasus (Creswell, 2007).

\section{Sumber Data}

1. Anak autis

Pada penelitian ini, partisipan penelitian tidak hanya anak laki-laki tetapi ada pula anak perempuan. $\mathrm{P} 1$ berinisial $\mathrm{G}$ berjenis kelamin perempuan dan merupakan anak pertama dari tiga bersaudara, berusia 9 tahun dan duduk di kelas 3 SD Inklusi Sinar Talenta. Sedangkan P2 berinisial $\mathrm{R}$ berjenis kelamin laki-laki, merupakan anak pertama dari tiga bersaudara, berusia 10 tahun dan saat ini duduk di kelas 2 SD Inklusi Multi Talenta.

2. Orangtua

3. Guru/wali kelas

\section{Teknik pengumpulan data}

1. Observasi

Observasi adalah sistem atau rencana untuk mengamati perilaku. Selain itu sebagai pengamatan dan pencatatan secara sistematik terhadap gejala yang tampak pada objek penelitian (Margono, 2003). Dalam penelitian ini, peneliti melibatkan orangtua dan guru untuk melakukan observasi terhadap anak. Dalam proses observasi, peneliti telah menyusun 
lembar observasi yang menjadi panduan orang tua dan guru/wali kelas dalam melakukan observasi terhadap anak.

Pencatatan frekuensi dengan instrumen observasi yang digunakan yakni panduan dari Autism Disorder (AD) Questionnaire for parent, PMII Activity Observastion for young children dari National Professional Development Center on ASD and FPG Child Development Institute (2008) dan observation form for recording symptoms that may reflect autistic disorder and positive behaviors (Adrien et al, 1987 and Fliptek et al, 1999).

\section{Wawancara}

Wawancara adalah percakapan dengan maksud tertentu. Percakapan itu dilakukan oleh dua pihak, yaitu pewawancara (interviewer) yang mengajukan pertanyaan dan terwawancara, (interviewee) yang memberikan jawaban atas pertanyaan itu (Moleong, 2007) interview (wawancara) merupakan alat pengumpulan data yang sangat penting dalam penelitian komunikasi kualitatif yang melibatkan manusia sebagai subjek (pelaku, aktor) sehubungan dengan realitas atau gejala yang dipilih untuk dipilih (Pawito, 2008).

Dalam membuat interview guide, peneliti menggunakan hasil dari lembar observasi yang telah diisi oleh partisipan/narasumber. Selain menggunakan hasil observasi, peneliti juga membuat interview guide berdasarkan 4 faktor penting dalam interaksi sosial yakni imitasi, sugesti, identifikasi, dan simpati dari Sunaryo (2013) dan Soekanto (2013).

Peneliti juga menggunakan panduan wawancara dari Schopler, Reichler \& Renner (1986) dan Schreibman (1988) yakni observational guidelines dengan 7 (tujuh) tema besar (child's ability to make eye contact,child's interaction with toys, child's interation with her or his parents, child's speech, child's affect, child's motor patterns and activity level and child's interactions with examiners). Dalam penelitian ini, wawancara yang dilakukan dalam kurun waktu 9 (sembilan) kali, dengan mewawancarai guru dan orang tua.

\section{HASIL \& PEMBAHASAN}

Dari hasil analisis data didapat beberapa tema yang dapat menggambarkan interaksi sosial kedua partisipan yaitu: pola komunikasi (verbal dan non-verbal) pola bermain, perasaan atau emosi (positif, negatif, dan sayang), perilaku positif, respon sosial dan interaksi saudara kandung. Dalam penelitian ini, kedua partisipan saat ini mampu untuk berinteraksi dengan lingkungan di sekolah maupun di rumah. Gillin (2010) menyebutkan kontak mata dan komunikasi, merupakan dua syarat terjadi interaksi sosial. Secara non-verbal, kedua partisipan saat ini memiliki kontak mata yang mulai terbentuk secara alami dan spontan tanpa diminta untuk melawan bicaranya walaupun keduanya memiliki rentang waktu yang berbeda untuk mempertahankan kontak mata tersebut. Selain kontak mata, bahasa tubuh (komunikasi ekspresif) dan ekspresi wajah juga menjadi peran penting dalam berinteraksi dengan lingkungan sekitar. 
Mulyana (2008) mengungkapkan bahasa tubuh atau komunikasi ekspresif bertujuan untuk mempengaruhi orang lain tidak hanya dengan verbal tetapi juga non verbal. Komunikasi tersebut menjadi instrumen untuk menyampaikan perasaan-perasaan yang ada di dalam diri manusia. Hal tersebut, dikomunikasikan melalui pesan-pesan non verbal. Komunikasi eskpresif juga mengungkapkan keinginan yang disampaikan melalui bahasa tubuh atau simbol-simbol yang sudah disepakati (Anatasia; dalam Cahyanti dkk, 2014). Ketika berkomunikasi dengan orang lain, ekspresi wajah individu akan berubah tanpa melihat apakah individu tersebut sedang berbicara atau mendengarkan (Ruben dan Stewart, 2005). Seperti pada P1, yang lebih banyak menggunakan bahasa tubuh dan ekspresi wajah ketika berkomunikasi untuk menyampaikan apa yang P1 inginkan dengan menggerakkan tangan atau mengepalkan tangannya. Sedangkan P2 sangat jarang atau tidak memunculkan bahasa tubuh atau komunikasi ekspresi saat berbicara dengan lawan bicaranya dan sampai saat ini memilki kekurangan dalam berekspresi termasuk ketika berbicara.

Tidak hanya komunikasi non-verbal, komunikasi verbal menjadi hal penting dalam berinteraksi. Effendy (2002) menjelaskan komunikasi secara verbal adalah proses penyampaian suatu pesan oleh seseorang kepada orang lain untuk memberitahu atau mengubah sikap, pendapat, atau berperilaku baik secara lisan maupun langsung melalui media. Dalam berkomunikasi secara dua arah juga menjadi indikator pada penyandang autisme (Paul, 2008). Kedua partisipan saat ini mulai memiliki kemampuan untuk berkomunikasi secara dua arah (komunikator dan komunikan) dengana lawan bicaranya, walaupun kedua partisipan masih memiliki hambatan dalam memulai percakapan dan bergiliran dalam berbicara. Selain itu, kedua partisipan juga dapat meminta untuk bermain dengannya, menanyakan sebuah pertanyaan, dan menunjukkan sebuah mainan pada orang lain.

Paul (2008) mengungkapkan bahwa tipikal berkomunikasi pada anak autis yaitu memunculkan echolalia, sebuah kondisi ketika penyandang autisme menirukan berulangulang kata-kata yang didengar atau diingat meskipun tidak mengetahui maknanya. Selain itu, penggunaaan kata-kata yang tidak lazim (idiosyncratic words). Hal ini nampak pada kedua partisipan, masih memunculkan echolalia dalam beberapa percakapan dengan lawan bicaranya. Kedua partisipan sampai saat ini juga masih menggunakan kata-kata idiosinkratik yang kedua partisipan adaptasi dan tiru dari siaran televisi atau radio sehingga kedua partisipan cenderung pasif dalam beberapa pembicaraan dan kalimat yang disampaikan masih terdengar aneh dan kedua partisipan juga cenderung untuk mengoceh.

Selanjutnya, selain komunikasi menjadi hal terpenting dalam kehidupan sehari-hari, bermain juga menjadi salah satu hal terpenting khususnya bagi anak-anak. Parten (dalam Tedjasaputra, 2005) menyoroti kegiatan bermain sebagai sarana sosialiasasi dan sebagai bentuk interaksi antar anak. Walaupun anak autis juga diberikan kesempatan bermain dengan 
teman sebayanya, anak autime lebih memilih menyendiri/memgisolasi diri. Anak autis cenderung untuk menunjukkan repetitive dan stereotype tertentu dalam memainkan benda. Anak autis juga tidak memperlihatkan penggunaan yang sesuai dari benda-benda atau alat permainan (Tilton \& Otinger; dalam Frost dkk, 2008).

Pada kedua partisipan saat ini mampu untuk terlibat pada permainan pura-pura (symbolic pretend play) walaupun rentang waktunya tidak bertahan lama. Kedua partisipan lebih cenderung untuk bermain dengan aplikasi game handphone walaupun kedua orang tua partisipan dapat mengatur waktu untuk kedua partisipan dapat bermain game. Selain itu, Sekolah Inklusi Multi Talenta sering memberikan permainan berkelompok pada saat kegiatan kepramukaan dengan memberikan instruksi dan peralatan yang sama pada beberapa kelompok. Dalam beberapa permainan yang diadakan oleh pihak sekolah, kedua partisipan dapat memusatkan perhatian bersama (joint attention) dengan teman sekelasnya atau pun teman yang berbeda kelas dan mampu untuk melibatkan diri dalam permainan paralel dengan memperhatikan instruksi yang diberikan oleh guru.

Selain pola bermain yang berkaitan dengan interaksi saudara kandung, kedua partisipan memiliki kemampuan untuk dapat bermain dengan saudara dan tidak sepenuhnya mengisolasi dirinya. Hubungan saudara kandung memberikan kesempatan bagi manusia dalam sebuah kontak fisik dan emosional yang terus menerus bertahap kritis sepanjang kehidupan mereka. Hubungan yang permanen ini memberi kesempatan bagi saudara kandung untuk memiliki pengaruh yang sangat besar antara satu sama lain melalui interaksi longitudinal (Hapsari, 2001). Sampai saat ini interaksi kedua partisipan dengan saudaranya tidak hanya dapat mengajak saudaranya bermain tetapi juga dapat menjalin interaksi seperti menonton televisi bersama dan kedua partisipan lebih cenderung untuk dekat pada adik bungsunya. Keduanya juga dapat melaporkan apapun yang terjadi pada adik bungsunya seperti adiknya mengompol, buang air besar, dan terluka.

Interaksi saudara kandung juga melibatkan emosi yang berpengaruh besar pada hubungan antar saudara seperti yang sudah dijelaskan sebelumnya. Anak autis mengalami ketidakmampuan untuk melakukan kontak afeksi dengan orang lain dan sulit membaca ekspresi orang lain, mengalami kesulitan emosi-emosi tertentu, dan kesulitan mengekspresikan emosinya (Castelli, 2005).

Emosi merupakan reaksi menyenangkan atau tidak menyenangkan terhadap suatu peristiwa tertentu (Mashar, 2008). Pada kedua partisipan, ditemukan tiga emosi yang muncul yakni emosi negatif, emosi positif, dan emosi sayang, Pada emosi negatif merupakan emosi yang menimbulkan dampak yang tidak menyenangkan bagi orang yang merasakannya. Sedangkan emosi positif merupakan emosi yang menimbulkan dampak atau reaksi menyenangkan pada orang yang merasakannya (Safaria dan Nofrans, 2012). Pada emosi negatif, kedua partisipan menginvestasikan emosi negatif dengan berteriak dan menangis. 
Namun, hal tersebut dikarenakan ada alasan tertentu atau ada penyebab seperti mainan, makanan atau barangnya yang direbut oleh temanya.

Untuk emosi positif, kedua partisipan menginvestasikannya dengan tertawa. Hal tersebut dimunculkan karena ada hal lucu atau alasan tertentu yang membuat kedua partisipan tertawa. Tidak hanya emosi positif dan negatif, emosi sayang juga dimunculkan oleh kedua partisipan. Emosi sayang didapat berdasarkan sumber stimulus yang menjadi penyebab emosi ini muncul adalah orang dan benda. Respon dari emosi ini seperti mencium, memeluk dan mendekati orang yang disayang (Ramdhani dan Thiomina, 2009).

Kedua partisipan pun memunculkan emosi sayang pada orangtuanya dengan memeluk dan mencium. Secara spesifik, pada P1 memunculkan emosi sayang pada anggota keluarganya. Dalam anggota keluarga, P1 lebih menyayangi ayahnya. Namun hal tersebut tidak menyurutkan rasa sayang subjek terhadap anggota keluarganya yang lain. Selain itu, $\mathrm{P} 1$ juga memiliki emosi sayang terhadap adik bungsunya dan senang untuk menjaga adiknya. Sedangkan untuk P2, lebih banyak memunculkan emosi negatif seperti sering marah, takut sendirian, takut dengan gelap, dan menjadi kesal ketika ada noda di bajunya. Emosi sayang secara spesifik dimunculkan oleh P2 seperti memeluk dan mencium orang tuanya namun tergantung pada keadaan mood-nya. Jika P2 dalam keadaan mood yang tidak baik seperti kesal pada orang tuanya, P2 akan marah dan menjauhi orang tuanya.

Tidak hanya emosi yang menjadi hal penting dalam menjalin kontak fisik dengan lingkungan. Namun, bagaimana kedua partisipan dapat merespon stimulus-stimulus eksternal. Respon dalam tentunya menjadi timbal balik dalam menjalin interaksi sosial dengan lingkungan luar. Respon sosial merupakan salah satu kekurangan bagi penyandang autisme. Ozonoff et al (2005) menjelaskan bahwa penyandang autisme kekurangan dalam menunjukkan ketertarikan pada teman sebaya, cenderung untuk tidak memperhatikan pendamping atau pengasuh, tidak berbagi pengalaman bahagia pada pendamping, tidak menyapa orang lain, dan tidak ada inisiatif atau respon untuk pemusatan perhatian bersama. Selanjutnya, kekurangan penyandang autisme dalam bentuk respon sosial misalnya kekurangan dalam perhatian bersama dan respon ketika namanya dipanggil (Dawson, 2008). Hal ini nampak pada kedua partisipan yang sampai saat ini memunculkan respon misalnya berbalik muka ketika dipanggil namanya walaupun terkadang masih tidak merespon ketika dipanggil, masih mengabaikan orang yang berusaha mendekatinya, dan terkadang cenderung untuk menyendiri dan kedua partisipan masih tidak secara spontan berbagi pengalaman dengan orang lain.

Kedua partisipan juga masih sulit untuk berteman dan nampak tidak tertarik untuk berteman. Kedua partisipan jugat terkadang melakukan hal yang tidak sepantasnya untuk dilakukan yang terlihat tidak sesuai dengan norma atau aturan yang ada. Tetapi saat ini, kedua partisipan masih nampak mulai memunculkan rasa empatinya terhadap orang 
terdekatnya seperti saudara kandungnya walaupun keduanya masih nampak tak peduli dengan lingkungan sekitarnya. Selain itu, kedua partisipan juga memunculkan respon lain seperti mendekat atau melekat seperti bayi pada orang-orang terdekat yang sudah keduanya kenal.

Selain rasa empati yang mulai muncul pada anak autis walaupun tidak hanya terlihat kecil kemungkinannya, namun anak autis juga dapat memunculkan perilaku positif yang dapat dilakukan oleh anak normal lainnya. Bovey dan Strain (2008) menjelaskan perilaku positif dalam interaksi sosial adalah interaksi yang terjadi antara teman sebaya yang positif dan berhasil untuk kedua anak yang terlibat. Interaksi teman sebaya ini penting karena mengarah pada perkembangan sosial dan emosional yang positif pada anak-anak. Hal ini penting untuk diajarkan oleh anak-anak dalam keterampilan positif yang dapat mereka gunakan untuk berinteraksi dengan teman-temannya.

Keterampilan yang berguna untuk berinteraksi dengan teman sebaya dan membangun hubungan sosial seperti mendapat perhatian teman, berbagi barang, mainan atau materi, meminta barang dari teman, memberikan ide bermain pada teman, mengatakan sesuatu yang baik pada teman, saling memperhatikan, dan saling membantu. Dalam hal ini guru memberikan anak-anak peluang di setiap harinya untuk berinteraksi satu sama lainnya dengan menggunakan keterampilan yang ditargetkan. Hal ini nampak pada kedua partisipan yang mampu untuk melihat teman sebayanya, mau untuk bertukar bahan, dan meminta bantuan ketika membutuhkan pada orang tua atau gurunya. Selain itu, Sekolah Inklusi Multi Talenta juga memberikan metode pengajaran dan permainan yang mengajarkan anak untuk dapat bekerja sama dengan teman, mampu menghargai teman yang berbeda kelasnya, berkompetisi secara sehat dan berinteraksi dengan teman-teman sekolahnya. Hal ini nampak pada kedua partisipan yang dapat menunggu giliran dalam beberapa aktivitas dan mengikuti arahan atau pun orangtuanya dan bekerjasama dalam mengikuti arahan bersama dengan temannya serta instruksi dari guru.

\section{SIMPULAN DAN SARAN}

Berdasarkan hasil penelitian ini, dapat disimpulkan bahwa kedua partisipan saat ini mampu untuk berinteraksi dengan lingkungan di sekolah maupun di rumah. Hal tersebut dapat dilihat dari gambaran interaksi sosial kedua partisipan mulai dari pola komunikasi verbal dan non-verbal, pola bermain, perasaan atau emosi, respon sosial, perilaku positif, dan interaksi saudara kandung. Secara pola komunikasi, kedua partisipan mulai dapat membuat kontak mata dan berkomunikasi dua arah walaupun ketika kedua kedua partisipan menjawab pertanyaan, masih menggunakan kata-kata yang tidak lazim atau memunculkan echolalia, atau menjawab tidak sesuai dengan apa yang ditanyakan. Pola bermain kedua partisipan saat ini mampu untuk terlibat dalam permainan pura-pura (symbolic pretend play) walaupun 
rentang waktunya tidak bertahan lama dan kedua partisipan juga dapat mengajak atau diajak oleh teman atau saudaranya untuk bermain bersama.

Pada aspek emosi, kedua partisipan mulai memunculkan emosi positif, negatif dan sayang. Kedua partisipan menginvestasikan emosi positif misalnya tertawa. Kemudian emosi negatif, keduanya menginvestasikannya dengan berteriak dan menangis. Selain itu emosi sayang, kedua partisipan memunculkan emosi tersebut dengan mencium dan memeluk orang tuanya. Selain emosi, respon sosial juga menjadi hal penting dalam berinteraksi, ketika kedua partisipan mulai dapat berbalik muka ketika namanya dipanggil walaupun keduanya terkadang masih tidak merespon ketika dipanggil dan mengabaikan orang berusaha mendekatinya serta cenderung untuk menyendiri. Kedua partisipan saat ini masih memiliki kesulitan untuk berteman dan peminatan untuk berteman serta tidak secara spontan untuk berbagi pengalaman dengan orang lain.

Kesulitan dalam merespon, tidak menutup kemungkinan kedua partisipan dapat memunculkan perilaku positif misalnya mampu untuk melihat teman sebayanya, mau untuk bertukar barang dan meminta bantuan ketika membutuhkan pada orang tua atau gurunya. Tidak hanya di sekolah, namun di rumah interaksi antara saudara kandung pun dimunculkan oleh kedua subjek misalnya menonton televisi bersama dan kedua partisipan lebih cenderung untuk dekat pada adik bungsunya. Keduanya juga dapat melaporkan apapun yang terjadi pada adik bungsunya seperti adiknya mengompol, buang air besar, dan terluka. Selain orang tua, pihak sekolah terutama guru memiliki peran penting dalam perkembangan anak berkebutuhan khususnya anak autis yang memiliki kesulitan dalam berinteraksi. Tentunya dengan kegiatan-kegiatan yang dibuat oleh pihak sekolah akan meningkatkan level interaksi sosial pada anak autis. Kemudian saran yang dapat diberikan seperti berikut :

\section{Orang tua}

Untuk orang tua yang memiliki anak autis, ada baiknya jika lebih sering untuk membawa anak pada lingkungan masyarakat luas, agar interaksi anak tidak hanya terbatas pada lingkungan sekolah, namun mencoba untuk memperluas interaksi anak dengan lingkungan di sekitar rumah dan mengurangi penggunaan handphone terutama game yang digunakan secara online. Selain itu, mencoba untuk mengenalkan lebih banyak teman pada anak setidaknya teman yang ada di sekitar rumahnya.

\section{Guru dan pihak sekolah}

Untuk pihak sekolah inklusi SD Multi Talenta yang memiliki banyak karakteristik anak kebutuhan khusus terutama anak autis, untuk dapat memberikan kegiatan yang dapat meningkatkan interaksi sosial anak di dalam maupun di luar kelas misalnya permainan berkelompok atau satu lawan satu, menambah peralatan bermain anak, ruang bermain anak dan menggunakan metode belajar sambil bermain. Pihak sekolah juga perlu untuk 
mengenalkan lebih banyak teman yang berbeda kelas kepada anak seperti mengadakan kegiatan olahraga dengan kelas lain atau permainan berkelompok dengan kelas lain.

\section{Penelitian Selanjutnya}

Untuk penelitian selanjutnya, disarankan untuk meneliti bagian aspek attachment anak autis dengan orang terdekatnya atau dengan orang asing yang perlu diteliti. Selain itu, untuk penelitian selanjutnya dapat mempertimbangkan lembar observasi dengan menggunakan attachment behavior form dari Akdemir et al (2009). Pada penelitian berikutnya, ada baiknya untuk mempertimbangkan kunjungan ke rumah atau pun ke sekolah partisipan, dan wawancara berkala khususnya dengan guru. Pada penelitian selanjutnya juga perlu untuk memperhatikan level keparahan pada setiap anak autis yang akan dijadikan partisipan penelitian.

\section{DAFTAR PUSTAKA}

Akdemir, D., Pehlivantürk, B.,Unal, F, \& Ozusta, S. (2009). Comparison of attachment-related social behaviors in autistic disorder and development disability. Turkish Journal of Psychiatry, 20, 105-117.

American Psychiatric Association. (2000). Diagnostic and statistical manual of mental disorders (4th Rev. ed.). Washington, DC: American Psychiatric Association.

American Psychiatric Association. (2013). Diagnostic and statistical manual of mental disorder fifth edition. United States of America: America Psychiatric Publishing.

Badan Pusat Statistik Jakarta Pusat. (2010). Statistik indonesia tahun 2010. Jakarta Pusat: Badan Pusat Statistik.

Baron-Cohen, S. \& Belmonte, M. K. (2005). Autism: A window onto the development of the social and the analytic brain. Annual Review Neuroscience, 28, 109-126.

Baron, R., \& Byrne, D. (2004). Psikologi sosial. Jakarta: Penerbit Erlangga

Bellini, S. (2006b). Building social relationships : A systematic approach to teaching social interaction skills to children and adolscent with autism spectrum disorders and other social difficuties. Shawnee Mission, KS: Autism Asperger Publishing.

Bovey, T \& Strain, P. (2008). Promoting positive peer social interactions. Center on the social and emotional foundations for early learning. United State: Department of Health and Human Services, Administration for Children and Families.

Cahyanti, M.N., Hitipeuw, I., \& Huda, A. (2014). Peningkatan kemampuan berbahasa ekspresif dan reseptif anak autis dengan menggunakan pendekatan ABA (applied behavior analysis). Jurnal P3LB, 1(2), 125-129. 
Creswell, J.W. (2007). Qualitative inquiry \& reseacrh design: Choosing among five approach, third edition. Thousand Oaks, CA: Sage.

Cooke, T.P., \& Apolloni, T. (1976). Developing positive social- emotional behaviors: A study of traning and generalization effects. Journal of Applied Behaviors Analysis, 9, 65-78. Doi: 10.1901/jaba.1976.9-65.

Dawson, G. (2008). Early behavioral intervention, brain plasticity and the prevention of autism spectrum disorder. Development and Psychopathology, 20, 775-803.

Deshinta, et al. (2015). Pengaruh metode glenn doman terhadap kemampuan interaksi sosial anak autis di SLB-B dan Autis TPA (Taman Pendidikan dan Asuhan) kabupaten Jember. E-jurnal Pustaka Kesehatan,3 (1), 66-73.

Effendy, O. U. (2002). IImu komunikasi teori dan praktek. Bandung: PT. Remaja Rosdakarya.

Frost, J. L., Wortham, S. C., \& Reifel, S. (2008). Play and child development. New Jersey: Pearson.

Gillin. (2010). Interaksi sosial pada anak autis. Jakarta : PT. Rineka Cipta.

Hapsari, I. (2001). Pengaruh Saudara Kandung dalam Perkembangan Interaksi Sosial Penyandang Autisme. Skripsi (tidak diterbitkan). Jakarta:Fakultas Psikologi Universitas Indonesia.

Huzaemah. (2010). Kenali autisme sejak dini. Jakarta: Pustaka Populer Obor.

Kaplan \& Sadock. (2010). Buku ajar psikiatri klinis (2nd Ed). Jakarta : EGC.

Kumalaningrum R. (2012). Pola kalimat bercerita anak autis: studi kasus terhadap tiga anak autis usia 8-11 tahun. Skripsi (tidak diterbitkan). Jakarta: Universitas Indonesia.

Margono.(2003). Metodologi penelitian pendidikan. Jakarta: Rineka Cipta.

Meleong, L. J. (2007). Metodologi penelitian kualitatif. Bandung: PT. Remaja Rosdakarya.

Mulyana, D. (2008). Ilmu komunikasicetakan keduabelas. Bandung : PT. Remaja Rosdakarya. National Association of School Psychology. (2002). Social skill : Promoting positive behavior, academic success and school safety. Bethesda: East West Highway

Ozonoff, S., Williams, B.J., Landa, R. (2005). Parental report of the early development of children with regressive autism. The Delays-plusregression Phenotype Autism, 9, 461486.

Paul, R., (2008). Intervention to improve communication in autism. Child and Adolescent Psychiatric Clinics of North America, 17,835-856. doi:10.1016/j.chc.2008.06.011.

Peraturan Menteri Pendidikan Nasional. (2009). Pendidikan inklusif bagi peserta didik yang memiliki kelainan dan memiliki potensi kecerdasan dan/atau bakat istimewa. Jakarta: Depdiknas.

Rahayu, R. (2017). Peran Guru dalam mengembangkan interaksi sosial anak autis di SD AL Firdaus. Skripsi (tidak diterbitkan).Surakarta: Fakultas Keguruan dan IImu Pendidikan Universitas Muhammadiyah 
Ramdhani, N \& Thiomina, R. (2009). Mengenali pola emosi anak-anak autistik. Yogyakarta: Fakultas Psikologi Universitas Gadjah Mada

Ruben, B.D \& Stewart, L.P. (2005). Communication and human behavior. USA: Pearson

Safaria, T., \& Nofrans, E. S. (2012). Manajemen emosi: Sebuah panduan cerdas bagaimana mengelola emosi positif dalam hidup anda. Jakarta: Bumi Pustaka

Sari, I. (2009). Nutrisi pada pasien autis. Jakarta: Cermin Dunia Kedokteran

Skjorten , M .(2003). Menuju inklusi dan pengayaan, artikel dalam Johsen B.H \& Skjorten MD menuju inklusi, pendidikan kebutuhan khusus sebuah pengantar. Bandung: Prog.

Soekanto, S (2013). Sosiologi suatu pengantar. Jakarta: PT Raja Grafindo Persada.

Sunaryo. (2013). Psikologi untuk keperawatan. Jakarta: EGC.

Tedjasaputra, M. (2005). Bermain, mainan, dan permainan untuk pendidikan usia dini. Jakarta: Grasindo

William, S., Keonig, K., \& Scahill, L (2006). Social Skills development in children with autism spectrum disorders: A review of the intervention research. Journal Autisme Development Disorder. doi 10.1007/s10803-006-0320-x. Retrieved from https://www.researchgate.net/publication/6605887_Social_Skills_Development_in_C hildren_with_Autism_Spectrum_Disorders_A_Review_of_the_Intervention_Research Yosep. (2010). Keperawatan jiwa. Bandung: PT. Refika. 